\section{Water in alkali feldspar: \\ The effect of rhyolite generation on the lunar hydrogen budget}

\section{R.D. Mills ${ }^{1 \#,}$ J.I. Simon ${ }^{1 *}$, C.M.O'D. Alexander ${ }^{2}$,} J. Wang ${ }^{2}$, E.H. Hauri ${ }^{2}$

\begin{abstract}
OPEN 2 ACCES
Abstract

doi: 10.7185/geochemlet.1712

Recent detection of indigenous hydrogen in a diversity of lunar materials, including volcanic glass (Saaletal, 2008), meltinclusions (Hauri et al. 2011), apatite (Boyce et al 2010; McCubin et al, 2010), and plagioclase (Hui et al, 2013) suggests water played a role in the chemical differ diferentint and mineral inthe a water initially existed in the lunar magma ocean (Hui et al., 2013) whereas measurements in apatite, found as a minor minet in lunar rocks, representing younger potassium-enriched melt predict a bulk Moon with $<100$ ppm water. Here we show that water in alkali feldspar, a common mineral in potassium-enriched rocks, can have $\sim 20 \mathrm{ppm}$ water, which implies magmatic water contents of $\sim 1 \mathrm{wt}$. \% in chemically evolved rhyolitic magmas. The source for these wet, potassium-rich magmas probably contained $\sim 1000 \mathrm{ppm} \mathrm{H}_{2} \mathrm{O}$. Thus, lunar granites with ages from 4.3-3.9 Ga (Meyer et al., 1996) likely crystallised from relatively wet melts that degassed upon crystallisation. Geochemical surveys by the Lunar Prospector (Jolliff et al., 2011) and Diviner Lunar Radiometer Experiment (Glotch et al., 2010; Jolliff et al., 2011) indicating the global significance of evolved igneous rocks suggest that the formation of these granites removed water from some mantle source regions, helping to explain the existence of mare basalts with $<10 \mathrm{ppm}$ water, but must have left regions of the interior relatively wet as seen by the water content in volcanic glass and melt inclusions. Although these early-formed evolved melts were water-rich, their petrogenesis supports the conclusion that the Moon's mantle had $<100 \mathrm{ppm}$ water for most of its history.
\end{abstract}

Received 19 August 2016 | Accepted 1 November 2016 | Published 28 November 2016

Center for Isotope Cosmochemistry and Geochronology, Astromaterials Research \& Exploration Science, NASA Johnson Space Center, Houston, TX 77058, USA

Current address: Department of Geological Sciences, University of North Carolina, Chapel Hill, NC 27599, USA

Corresponding author (email: justin.i.simon@nasa.gov)

2. Department of Terrestrial Magnetism, Carnegie Institution of Washington, Washington, DC 20015-1305, USA

\section{Introduction}

Understanding the volatile budget of the Moon is important because it can have profound effects on melt viscosity (Dingwell et al., 1985; Baker and Vaillancourt, 1995), chemical diffusion (Harrison and Watson, 1983), and solidus temperatures (Johannes and Holtz, 1996). These properties control physiochemical processes of magmas, including degassing, which have significant effects on planetary differentiation. The lack of hydrous silicate phases and hydrothermal alteration in lunar samples returned by the Apollo missions are observations commonly used to suggest that the Moon is depleted in hydrogen (plus other volatile elements) when compared to Earth, and thus water is generally not considered important in the chemical and physical differentiation of the Moon. The relative depletion in volatile elements in the Moon is thought to have occurred during a giant impact between a proto-Earth and a Mars-sized object (Hartman and Davis, 1975; Canup and Asphaug, 2001) resulting in volatile depletion and a lunar magma ocean, although Earth may have received additional input of volatiles by impacts after Moon formation (Owen and Bar-Nun, 1995). For these reasons, the recent conflicting evidence for significant lunar water requires further investigation.

On Earth, water and halogen contents of igneous rocks generally correlate with other incompatible elements like $\mathrm{K}, \mathrm{Rb}$, Th, and $\mathrm{U}$ (e.g., Stolper and Newman, 1994). Recent spectroscopic data from the Moon (Klima et al., 2013) support this trend, with a positive correlation between water and Th. Modelling of lunar magma ocean crystallisation (Elkins-Tanton and Grove, 2011) predicts a similar chemical differentiation to that seen in magma systems on Earth, with the highest levels of hydrogen in the evolved melt residuum of the magma ocean (i.e. urKREEP). However, sample-based estimates of water content of KREEP-rich magmas from measurements of $\mathrm{OH}^{-}, \mathrm{F}$, and $\mathrm{Cl}$ in lunar apatites suggest a low water concentration in the KREEP component with 2 to 140 ppm magmatic water (McCubbin et al., 2010). Using these data Elkins-Tanton and Grove (2011) predict that the bulk water content of the magma ocean would have been $<10 \mathrm{ppm}$. In contrast, Hui et al. (2013) estimate water contents of 320 ppm for the bulk Moon and 1.4 wt. \% for urKREEP from water measured in lunar anorthosite.

In order to address these discrepant estimates for the water content in KREEP and ultimately the bulk water content of the Moon, we measured water in nominally anhydrous minerals in the KREEP-rich sample 15405,78. We present data for water from alkali feldspar and a silica polymorph from granitoid clasts. The measurements of water in lunar alkali feldspar are the first of their kind. Alkali feldspar and apatite are the two most important mineralogical carriers of the KREEP component; as alkali feldspar is the main K phase and apatite ( \pm whitlockite) are the main REE and P phases on the Moon. These data in conjunction with $\mathrm{OH}^{-}, \mathrm{F}$, and $\mathrm{Cl}$ data from apatites in rocks with varying amounts of alkali feldspar are used to determine the water distribution in the KREEP reservoir and whether water estimates from KREEP-rich rocks suggest a dry or wet bulk Moon. 


\section{Results and Discussion}

NanoSIMS ion microprobe measurements of water in alkali feldspar and a silica polymorph from sample 15405,78 were employed following the approach of Hauri et al. (2006; see Supplementary Information). In Apollo sample 15405,78 granitoid clast xenoliths are found in the groundmass (Ryder, 1976) and generally consist of intergrowths of alkali feldspar and a silica polymorph (Fig. 1). In the studied sample plagioclase is largely absent, only occurring as small patches in a few clasts. The water concentration in the alkali feldspar is uniform with values of $\sim 20$ ppm $\mathrm{H}_{2} \mathrm{O}$ (Table 1). Reconnaissance scanning electron microscope and electron microprobe mineral compositional analysis show that the alkali feldspar is two-phase, with some high Ba zones (Fig. 1), but there is no observed variation in water content between the high- and low-Ba feldspar (although the vast majority of the analyses were made on the low-Ba feldspar). The silica polymorph $\mathrm{OH}^{-}$measurements are equivalent to measurements from the anhydrous Suprasil glass standard.

Table 1 NanosIMS data for alkali feldspar and $\mathrm{SiO}_{2}$ phases from 2 clasts found in Apollo sample 15405,78. For alkali feldspar, data from 4 regions of interest (ROI) are presented, taken from 2 different clasts. Raw - Suprasil values are the calculated concentration data for the alkali feldspar minus the baseline calculated from the Suprasil anhydrous glass. Raw - average $\mathrm{SiO}_{2}$ are the calculated concentration data for the alkali feldspar minus the average from the $\mathrm{SiO}_{2}$ phase from the clasts.

\begin{tabular}{|l|c|c|c|c|c|c|}
\hline \multirow{2}{*}{} & \multicolumn{7}{|c|}{ Alkali feldspar (ppm) } \\
\cline { 2 - 8 } & ROI 1 & ROI 2 & ROI 3 & ROI 4 & Average & 2 S.E. \\
\hline Raw & 22.8 & 22.3 & 20 & 21.3 & 21.6 & 1.25 \\
\hline Raw - Suprasil & 20.7 & 20.2 & 17.9 & 19.2 & 19.5 & 1.25 \\
\hline Raw - average $\mathrm{SiO}_{2}$ & 20.1 & 19.6 & 17.3 & 18.6 & 18.9 & 1.25 \\
\hline \multirow{2}{*}{ Raw } & ROI 1 & ROI 2 & $\mathrm{ROI}_{2}$ 3 & Average & 2 S.E. & \\
\cline { 2 - 8 } & 2.89 & 2.39 & 2.78 & 2.68 & 0.304 & \\
\hline
\end{tabular}

Hydrogen contained in nominally anhydrous minerals is normally in the form $\mathrm{H}_{2} \mathrm{O}$ or $\mathrm{OH}^{-}$(Johnson and Rossman, 2004) and water contents in alkali feldspars from Earth vary from 10s to 1000s of ppm (Johnson and Rossman, 2004). In alkali feldspar in plutonic rocks on Earth the hydrogen is mostly found as $\mathrm{H}_{2} \mathrm{O}$ and in volcanic rocks it is generally $\mathrm{OH}^{-}$(Johnson and Rossman, 2004). Johnson and Rossman (2004) hypothesise that the speciation of hydrogen in the feldspar is a function of the species in the liquid in equilibrium with the crystal. Thus, the $\mathrm{H}_{2} \mathrm{O}$ in plutonic rocks on Earth might be due to late stage hydrous-fluid/rock interactions in the crust. Due to the lack of evidence of post crystallisation hydous-fluid/mineral interactions in sample 15405,78, we suggest

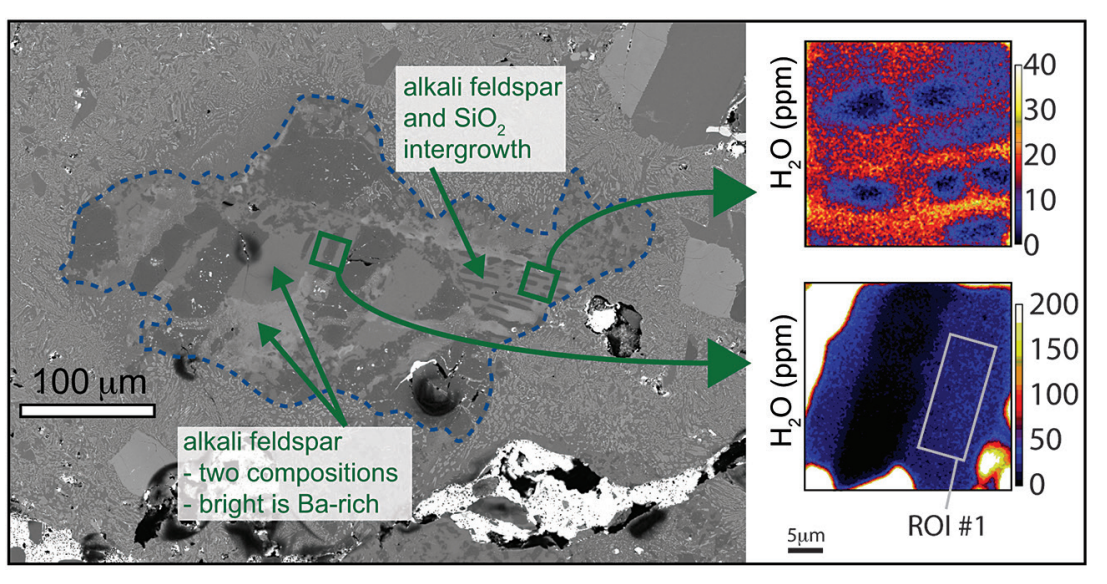

Figure 1 BSE image of granitoid clast (outlined in dashed line) from sample 15405,78, on the left. Clast consists of alkali feldspar and a silica phase. The variation in brightness of the feldspar relates to Ba (i.e. bright has more Ba). On the right are chemical maps obtained by NanoSIMS at DTM. Water correlates with mineralogy. The alkali feldspar consistently has $\sim 20 \mathrm{ppm} \mathrm{H}_{2} \mathrm{O}$. The silica phase has similar water contents as the blank obtained on anhydrous glass (2-3 ppm)

water was incorporated into the feldspar during crystallisation from the silicate melt. However, future work to understand whether hydrogen in the alkali feldspar studied here is in the form $\mathrm{OH}^{-}$or $\mathrm{H}_{2} \mathrm{O}$ would help clarify the origin of the hydrogen. In addition, $\mathrm{D} / \mathrm{H}$ isotopic analyses on the feldspar would help assess if there is an exodemic component.

Estimates for the water distribution coefficient $(D)$ between alkali feldspar and a representative range of felsic host melts can be determined from the Bishop Tuff of California, a well-studied, compositionally zoned rhyolite. Johnson and Rossman (2004) measured $90 \mathrm{ppm} \mathrm{OH}^{-}$in sanidines from the tuff; however, recalculation using a new molar absorption coefficient for sanidine (Mosenfelder et al., 2015) produces a value of $65 \mathrm{ppm}$. Water contents from melt inclusions from the Bishop Tuff show a range from 2.3 to $6.0 \mathrm{wt}$. \% (Schmitt and Simon, 2004). Thus the range of $D$ for water in alkali feldspar from the Bishop Tuff is 0.001 - 0.004 using the full range in values for both the sanidine and the melt inclusions. These values are similar to a $D$ obtained for plagioclase feldspar in felsic melt of 0.004 (Johnson, 2006). It should be noted that because the Moon formed under rather reducing conditions the effect of oxygen fugacity on $\mathrm{H}$ solubility in feldspar may be important. Experiments by Yang et al. (2012) show that the H solubility is higher $(2-3 x)$ at very reducing conditions, but because the oxygen fugacity during the crystallisation of the granitoids is unknown we cautiously use the range calculated from the Bishop Tuff. Using the range in $D$ of $0.001-0.004$ we obtain an estimate of 0.5 to 2 wt. \% water in the felsic lunar melt (Fig. 2) at the time of alkali feldspar crystallisation for the granitoid clasts from sample 
15405,78. Given that alkali feldspar and the silica polymorph make up the vast majority of these granitoid clasts, the water estimate at the time of alkali feldspar crystallisation closely approximates the magmatic value. Because the melt was initially not water saturated (Johannes and Holtz, 1996) little water should have been lost prior to crystallisation. Despite the fact that 0.5 to $2 \mathrm{wt}$. \% water is the wettest magma inferred for the Moon, it still would likely not stabilise hydrous phases (Merzbacher and Eggler, 1984). Instead, the water and halogens likely left the system as a highly water-rich fluid.

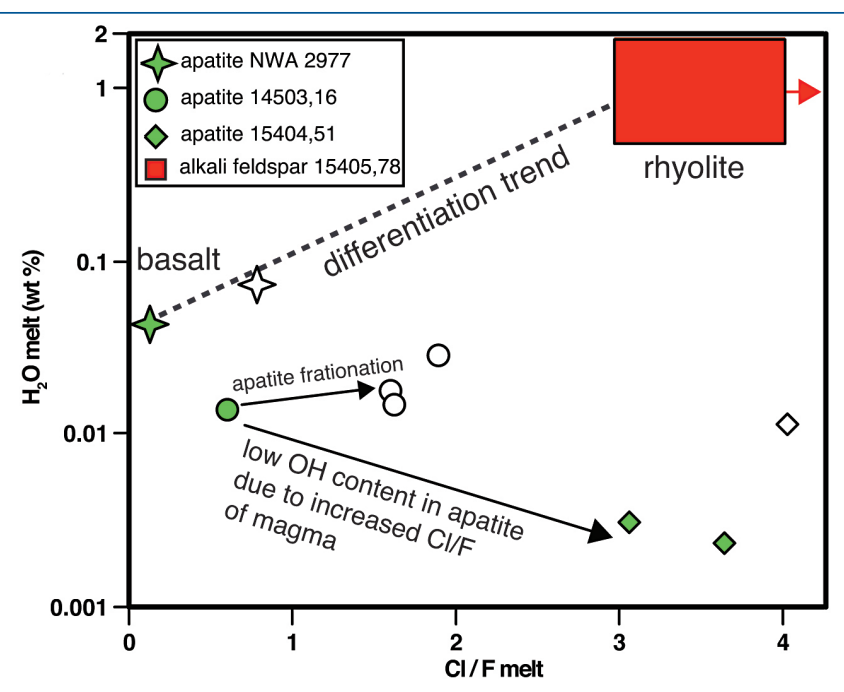

Figure 2 Plot of the estimated $\mathrm{Cl} / \mathrm{F}$ ratio of magma versus estimated water content for lunar magmas ( $y$-axis in log scale). Apatite data are from McCubbin et al. (2010). Water estimates from apatite assume $95 \%$ crystallisation prior to apatite crystallisation. CI/F melt estimate from apatite assume $D_{\mathrm{F}} / D_{\mathrm{Cl}}$ is 10 (Webster et al., 2009). Within individual samples, boundary layer crystallisation will create apatites with higher $\mathrm{Cl}$ and $\mathrm{OH}$ contents than those initially growing from their host magma, thus the lowest water estimates from each sample (green fill) differentiation trend is shown between basalt and rhyolite. For reference, $\mathrm{OH}^{-}$. Sata from differentiation trend is show be1047 (Robinson et of 0.001 wt. \%, and likely have CI/F ratios higher than 3 .

Volatile data from apatites in lunar basalts and alkali-suite clasts from McCubbin et al. (2010) show a conflicting trend with lower $\mathrm{OH}^{-}$and higher $\mathrm{Cl} / \mathrm{F}$ in rocks that have more alkali feldspar (i.e. more K-rich). Magmatic water estimates based on apatite measurements from an alkali-rich clast from Apollo sample 15404,51 range from as low as 0.001 to 0.014 wt. \% $\mathrm{H}_{2} \mathrm{O}$ (Fig. 2). As calculated by McCubbin et al. (2010) these estimates assume $95 \%$ crystallisation of the host magma prior to formation of the apatite. Although alkali feldspar is in clasts found in sample 15404,51, it is not a major phase. To compare our magma water estimates for lunar granitoids with apatite estimates from a similar rock type we use the published NanoSIMS $\mathrm{OH}^{-}$data of apatites from evolved lunar rocks (Barnes et al., 2014; Robinson et al., 2014) including the largest specimen of lunar granite, 14321,1047. Following the same approach as above yields apatite water estimates for the rhyolitic magmas at $<0.04 \mathrm{wt}$. \% $\mathrm{H}_{2} \mathrm{O}$. Excluding two outlier $\mathrm{OH}^{-}$measurements from Barnes et al. (2014) lowers the magmatic water estimate to $0.004 \mathrm{wt}$. \%. Thus, magmatic water estimates from alkali feldspar and apatite in petrologically similar lunar granitoid clasts differ by approximately 2 to 3 orders of magnitude.

Notably, the inferred magmatic water contents based on $\mathrm{OH}^{-}$in lunar apatite have recently been shown to be unreliable due to the co-dependent compatibilities of $\mathrm{F}, \mathrm{Cl}$, and $\mathrm{OH}^{-}$(Boyce et al., 2014). Specifically, fractionation of apatite within a single magma can remove $\mathrm{F}$, leading to later forming apatites with high $\mathrm{OH}^{-}$concentrations that produce inaccurate, high magmatic water estimates (Fig. 2). This likely explains the two highest $\mathrm{OH}^{-}$values from Robinson et al. (2014) and implies that apatite with the lowest $\mathrm{OH}^{-}$content in an individual sample (Fig. 2) should give the best estimate of magmatic water. More important is the fact that evolved magmas with high $\mathrm{Cl} / \mathrm{F}$ can crystallise apatite that generally excludes $\mathrm{OH}^{-}$, regardless of the water content of the magma (McCubbin et al., 2011; Boyce et al., 2014). Estimated Cl/F of magmas from mare basalts, alkali suite, and KREEP-rich rocks show a progression toward higher $\mathrm{Cl} / \mathrm{F}$ as magma compositions become more K-rich (Fig. 2). Associated with the increase in magma $\mathrm{Cl} / \mathrm{F}$ is a decrease in $\mathrm{OH}^{-}$in apatite, and thus an apparent decrease in magmatic water (Fig. 2).

\section{Implications}

Zircon ages from lunar granitic rocks (e.g., Meyer et al., 1996) span from 4.3 to 3.9 $\mathrm{Ga}$, with an age of $4.3 \mathrm{Ga}$ for 15405 . Thus, granitoids analysed here either reflect the end of extensive magma ocean solidification, or the beginning of secondary crust formation through partial melting, i.e. very small-scale partial melts during initiation of density driven stratification (i.e. local mantle overturn). Regardless of whether the granitoids represent the final liquids or the first partial melts of lunar magma ocean materials, the new data imply that high water content rhyolitic magmas existed locally in the lunar crust around $4.3 \mathrm{Ga}$ (Meyer et al., 1996). The reduced viscosity of these rhyolitic melts appear to have allowed them to easily ascend through the crust and possibly degas. The removal of water and chlorine from the lunar interior by the generation of these magmas would likely deplete some of the source regions of later magmatic activity (e.g., mare volcanism). Whether younger granites with different trace element compositions (e.g., 14321,1027; Warren et al., 1983) crystallised from similarly hydrous magmas is unknown.

The rhyolitic magmas are believed to represent a distilled component of the urKREEP reservoir, reflecting a 10-100x enrichment in water. If true, our data suggest urKREEP had between 50 and 2000 ppm water; consistent with a dry bulk 
Moon (1-50 ppm water; Elkins-Tanton and Grove, 2011) and much less than the 1 to 2 wt. \% predicted for urKREEP if the bulk Moon was as wet as suggested by Hui et al. (2013) from plagioclase in ferroan anorthosite. The discrepancy between the results and interpretations of Hui et al. (2013) and this study could be due to the hypotheses used to understand how each formed or the physical processes that affected the plagioclase from the primary crust differently than the later granitoid rocks (e.g., degassing).

If the granitoid rocks on the Moon were generally produced by hydrous magmas with $0.5-2$ wt. \% water ( 1 wt. \%), then the amount of granitic material on the Moon can be used to estimate the amount of water removed from the bulk Moon by felsic magmatism. Using the $\mathrm{K}_{2} \mathrm{O}$ concentration estimated for the silicate portion of the Moon (Longhi, 2006) there would be $\sim 0.02 \%$ alkali feldspar. Assuming that this alkali feldspar makes up $25-50 \%$ of the granitic rock of the Moon, then the bulk silicate Moon would be $\sim 0.1 \%$ granite. Thus, the bulk Moon water content would have been decreased by 10 ppm by felsic magmatism between 4.3 and $3.9 \mathrm{Ga}$. Globally, this early period of dehydration would have had a significant effect on the water content of the already dry bulk Moon, removing between a $1 / 4$ to mostly all of the water. The water depletion events were likely distributed heterogeneously within the mantle, depending on the $\mathrm{K}$ distribution. Some regions could have retained 1000s of ppm water that contributed to later magmatism, as seen in water contents in volcanic glass and melt inclusions from mare basalts.

\section{Acknowledgements}

NASA Curation is thanked for skillful processing of the Apollo sample used in the study. CAPTEM is thanked for sample allocations. The image used for the graphical abstract is credited to NASA/JSC/Arizona State University. We are grateful to Editor Bruce Watson and reviewers Rebecca Lange, Jed Mosenfelder, and one anonymous individual who helped improve this contribution. This work was supported by NASA LASER NNH10ZDA001N-0077 and SSW NH15ZDA001N-0411 grants to JIS, an Astrobiology Institute grant to CIW for CA and JW, and a NASA Postdoctoral Fellowship that supported RDM.

Editor: Bruce Watson

\section{Additional Information}

Supplementary Information accompanies this letter at www.geochemicalperspectivesletters.org/article1712

Reprints and permission information are available online at http://www. geochemicalperspectivesletters.org/copyright-and-permissions
Cite this letter as: Mills, R.D, Simon, J.I, Alexander, C.M.O'D., Wang, J., Hauri, E.H. (2017) Water in alkali feldspar: The effect of rhyolite generation on the luna hydrogen budget. Geochem. Persp. Let. 3, 115-123.

\section{References}

BAKER, D.R., VaillanCoURT, J. (1995) The low viscosities of $\mathrm{F}+\mathrm{H} 2 \mathrm{O}$-bearing granitic melts and implications for melt extraction and transport. Earth and Planetary Science Letters 132, 199-211.

Barnes, J.J., Tartèse, R., Anand, M., McCubbin, F.M., Franchi, I.A., Starkey, N.A., Russell, S.S. (2014) The origin of water in the primitive Moon as revealed by the lunar highlands samples. Earth and Planetary Science Letters 390, 244-252.

Boyce, J.W., LiU, Y., Rossman, G.R., Guan, Y., Eiler, J.M., Stolper, E.M., TAYLOR, L.A. (2010) Lunar apatite with terrestrial volatile abundances. Nature 466, 466-469.

Boyce, J.W., Tomlinson, S.M., McCubbin, F.M., Greenwood, J.P., Treiman, A.H. (2014) The lunar apatite paradox. Science $344,400-402$.

CANUP, R.M., AsPHAUG, E. (2001) Origin of the Moon in a giant impact near the end of the Earth's formation. Nature 412, 708-712.

Dingwell, D.B., SCARFE, C.M., Cronin, D.J. (1985) The effect of fluorine on viscosities in the system $\mathrm{Na}_{2} \mathrm{O}-\mathrm{Al}_{2} \mathrm{O}_{3}-\mathrm{SiO}_{2}$ : implications for phonolites, trachytes and rhyolites. American Mineralogist 70, 80-87.

ELKins-Tanton, L.T., Grove, T.L. (2011) Water (hydrogen) in the lunar mantle: Results from petrology and magma ocean modeling. Earth and Planetary Science Letters 307, 173-179.

Glotch, T.D., Lucey, P.G., BANDField, J.L., Greenhagen, B.T., Thomas, I.R., Elphic, R.C. Bowles, N., Wyatt, M.B., Allen, C.C., Donaldson Hanna, K., Paige, D.A. (2010) Highly Silicic Compositions on the Moon. Science 329, 1510-1513.

HARRISON, T.M., WATSON, E.B. (1983) Kinetics of zircon dissolution and zirconium diffusion in granitic melts of variable water content. Contributions to Mineralogy and Petrology 84, 66-72.

HARTMAN, WK., DAVIS, D.R. (1975) Satellite-sized planetesimals and lunar origin. Icarus 24, 504-515.

Hauri, E.H., Shaw, A.M., Wang, J., Dixon, J.E., King, P.L., Mandeville, C. (2006) Matrix effects in hydrogen isotope analysis of silicate glasses by SIMS. Chemical Geology 235, 353-365.

Hauri, E.H., Weinreich, T., Saal, A.E., Rutherford, M.C., Van Orman, J.A. (2011) High pre-eruptive water contents preserved in lunar melt inclusions. Science 333, 213-215

Hui, H., Peslier, A.H., Zhang, Y., NeAL, C.R. (2013) Water in lunar anorthosites and evidence for a wet early Moon. Nature Geoscience 6, 177-180.

JOHANNES, W., HolTZ, F. (1996) Petrogenesis and experimental petrology of granitic rocks. SpringerVerlag, Berlin.

JOHNSON, E.A. (2006) Water in nominally anhydrous crustal minerals: Speciation, concentration, and geologic significance. Reviews in Mineralogy and Geochemistry 62, 117-154

JOHNSON, E.A., Rossman, G.R. (2004) A survey of hydrous species and concentrations in igneous feldspars. American Mineralogist 89, 560-600.

Jolliff, B.L., Wiseman, S.A., Lawrence, S.L., Tran, T.N., Robinson, M.S., Sato, H., Hawke, B.R., Scholten, F., Oberst, J., Hiesinger, H., van Der Bogert, C.H., Greenhagen, B.T., GLOTCH, T.D., PAIGE, D.A. (2011) Non-mare silicic volcanism on the lunar farside Compton-Belkovich. Nature Geoscience 4, 566-571.

Klima, R., CAHILl, J., HagerTY, J., LAWRENCE, D. (2013) Remote detection of magmatic water in Bullialdus Crater on the Moon. Nature Geoscience 6, 737-741. 
LONGHI, J. (2006) Petrogenesis of picritic mare magmas: Constraints on the extent of early lunar differentiation. Geochimica et Cosmochimica Acta 70, 5919-5934.

McCubbin, F.M., Steele, A., Hauri, E.H., Nekvasil, H., Yamashita, S., Hemley, R.J. (2010) Nominally hydrous magmatism on the Moon. Proceedings of the National Academy of Sciences $107,11223-11228$

McCubbin, F.M., Jolliff, B.L., Nekvasil, H., Carpenter, P.K., Zeigler, R.A., Steele, A., ELARDO, S.M., LINDSLEY, D.H. (2011) Fluorine and chlorine abundances in lunar apatite: Implications for heterogeneous distributions of magmatic volatiles in the lunar interior Geochimica et Cosmochimica Acta 75, 5073-5093.

MerzBaCher, C., EgGLeR, D.H. (1984) A magmatic geohygrometer - Application to mount St. Helens and other dacitic magmas. Geology 12, 587-590.

Meyer, C., Williams, I.S., Compston, W. (1996) Uranium-lead ages for lunar zircons: Evidence for a prolonged period of granophyre formation from 4.32 to 3.88 Ga. Meteoritics \& Planetary Science 31, 370-387.

MosenfelDer, J.L., Rossman, G.R., JoHnson, E.A. (2015) Hydrous species in feldspars: A reassessment based on FTIR and SIMS. American Mineralogist 100, 1209-1221.

OwEN, T., BAR-NUN, A. (1995) Comets, impact, and atmospheres. Icarus 116, 155-116,

Robinson, K.L., Barnes, J.J., Tartèse, R., Nagashima, K., Hallis, L.J., Franchi, I.A., AMAND, M., TAYLOR, G.J. (2014) Primitive lunar water in evolved rocks? In $45^{\text {th }}$ Lunar and Planetary Science Conference. 1607.

RYDER, G. (1976) Lunar sample 15405: Remnant of a KREEP basalt-granite differentiated pluton. Earth and Planetary Science Letters 29, 255-268.

SaAl, A.E., Hauri, E.H., Cascio, M.L., Van Orman, J.A., Rutherford, M.C., CoOper, R.F. (2008) Volatile content of lunar volcanic glasses and the presence of water in the Moon's interior. Nature 454, 192-195

ScHMitT, A.K., SimON, J.I. (2004) Boron isotopic variations in hydrous rhyolitic melts: a case study from Long Valley, California. Contributions to Mineralogy and Petrology 146, 590-608.

STOLPER, E., NewMAN, S. (1994) The role of water in the petrogenesis of Mariana trough magmas. Earth and Planetary Science Letters 121, 293-325.

Warren, P. H., Taylor, G.J. Keil, K., Shirley, D.N., Wasson, J.T. (1983) Petrology and chemistry of two "large" granite clasts from the Moon: Earth and Planetary Science Letters 64, 175-185.

Webster, J.D., Tappen, C.M., Mandeville, C.W. (2009) Partitioning behavior of chlorine and fluorine in the system apatite-melt-fluid. II: Felsic silicate systems at $200 \mathrm{MPa}$. Geochimica et Cosmochimica Acta 73, 559-581.

YANG, X. (2012) An experimental study of $\mathrm{H}$ solubility in feldspars: Effect of composition, oxygen fugacity, temperature and pressure and implications for crustal processes. Geochimica et Cosmochimica Acto 97, 46-57. 